\title{
Factors influencing the maturation, fertilization and development of swamp buffalo oocyte in vitro
}

\author{
Lerma C. Ocampo $^{1,2}$, Lucia M. Rigos ${ }^{2}$ and Marlon B. Ocampo ${ }^{1,2}$ \\ ${ }^{1}$ Reproductive Biotechnology Unit, Philippine Carabao Center, Science City of Muñoz, Nueva Ecija, Philippines \\ $3120,{ }^{2}$ College of Veterinary Science and Medicine, Central Luzon State University, Science City of Muñoz, Nueva \\ Ecija, Philippines 3120
}

\begin{tabular}{|c|c|}
\hline $\begin{array}{l}\text { Article history } \\
\text { Received: } 3 \text { Feb, } 2016 \\
\text { Revised: } 29 \text { Feb, } 2016 \\
\text { Accepted: } 2 \text { Mar, } 2016\end{array}$ & $\begin{array}{l}\text { Abstract } \\
\text { Buffalo ovaries ( } \mathrm{n}=610 \text { ) were collected from the abattoir and the oocytes recovered } \\
\text { were matured, fertilized and the resulting zygotes were cultured in vitro. In } \\
\text { Experiment } 1 \text {, the maturation and fertilization rates of } \mathrm{O}_{1}-\mathrm{O}_{2} \text { oocytes were higher than } \\
\mathrm{O}_{3}-\mathrm{O}_{5} \text { oocytes. In Experiment } 2 \text {, the two batches of TCM- } 199 \text { medium used with } \\
\text { different hormonal supplementation did not influence the maturation and fertilization } \\
\text { of the oocytes at } 70.7-86.7 \% \text { and } 59.4-66.0 \% \text { respectively. In Experiment } 3 \text {, bull } \\
\text { variability was observed in terms of their capacity for fertilization. In Experiment } 4 \text {, } \\
\text { higher fertilization rate was observed in response to caffeine }(3-10 \mathrm{mg} / \mathrm{ml} \text { ) compared } \\
\text { to control. In Experiment } 5,1 \times 10^{6} \text { sperm } / \mathrm{ml} \text { concentration during fertilization had a } \\
\text { lower penetration rate }\left(43.0 \% \text { ) than } 5,10 \times 10^{6} \text { sperm/ } \mathrm{ml} \text { concentration }(68.4-71.0 \%) \text {. }\right. \\
\text { In Experiment } 6 \text {, development to the blastocyst stage in TCM-199 or mSOF medium } \\
\text { with or without cumulus cell monolayer had no significant difference }(11.5-22.2 \%) \\
\text { with total cell count ranging from } 84.6 \pm 11.2 \text { to } 91.4 \pm 12.2 \text {. Overall, the results showed } \\
\text { the importance of cumulus cells in the acquisition of developmental competence of } \\
\text { oocytes maturing in vitro and its subsequent fertilization. That, selection of appropriate } \\
\text { bull, its optimum sperm concentration, the choice of capacitating agent and its } \\
\text { concentration, the type of medium for culture of resulting zygotes is critical for } \\
\text { successful application of in vitro maturation, fertilization and culturing for mass } \\
\text { production of buffalo embryos. } \\
\text { Keywords: Embryos; fertilization; maturation; oocytes }\end{array}$ \\
\hline
\end{tabular}

To cite this article: Ocampo LC, LM Rigos and MB Ocampo, 2015. Factors influencing the maturation, fertilization and development of swamp buffalo oocyte in vitro. Res. Opin. Anim. Vet. Sci., 6(1): 24-31.

\section{Introduction}

Understanding the various mechanisms of fertilization has been limited due to technical problems on the study of gamete development, migration and interaction in situ condition. Thus, the development of an alternative approach in the study of fertilization under in vitro condition has become the interest of many researchers in solving the problems confronting mammalian fertilization. Probably, the first successful experiment on in vitro fertilization (IVF) was done in rabbit, using freshly ovulated oocytes (Dauzier et al., 1954). The group reported cytological changes associated with fertilization, but did not transfer the embryos to substantiate normal development in vivo of such in vitro fertilized oocytes. At that time, it was

\footnotetext{
*Corresponding author: Lerma C Ocampo, Reproductive Biotechnology Unit, Philippine Carabao Center, Science City of Muñoz, Nueva Ecija, Philippines 3120; E-mail: ocampomarlon29@ yahoo.com; Tel No: 09098868938
} 
appreciated that unless living young were obtained following transfer to recipients, the success of IVF as determined only by cytological changes may not be sufficiently proved. In buffalo, this important step was accomplished when live calves were born following the methods used in bovine (Ocampo et al., 2000; HufanaDuran et al., 2004, 2005, 2008). Since then, lots of experiments have been directed on improving the in vitro maturation, fertilization and culture (IVM/IVF/IVC) of buffalo oocytes. Among the significant advancement achieved includes the identification of time required for the completion of $1^{\text {st }}$ and $2^{\text {nd }}$ meiotic division (oogenesis), spermatogenesis, determination and understanding of the role of some agents (eg., heparin, caffeine, theophylline) on the induction of sperm capacitation and acrosome reaction and the role of some supplements in the acquisition of oocytes developmental competence to developed up to the blastocyst stage following fertilization (HufanaDuran et al., 1998; Totey et al., 1993a; Jainudeen et al., 1993; Ocampo et al., 2001a,b; 2002).

Despite this progress, however, the proportion of buffalo eggs being fertilized after IVM remained low compared to cattle (Madan et al., 1994a; Ocampo et al., 1996a; Gasparrini, 2002). A major limiting factor is the source and quality of frozen semen, thus requires testing of several bulls to accurately identify the few suitable for IVF (Aquino et al., 2015; Ocampo and Ocampo, 2015). Also, poor understanding of the mechanisms of capacitation (both for ejaculated and frozen-thawed spermatozoa) and the lack of knowledge of conditions for fertilization and normal development remained contributory to the problems associated with buffalo IVF. In this study, we planed to find the effect of oocyte quality, medium batch and hormone supplementation, bull, caffeine, sperm concentration and culture system for embryo development on the successful application of IVM/IVF/IVC techniques in swamp buffalo (SB).

\section{Materials and Methods}

\section{Media}

For maturation of oocytes, culture medium (TCM199; Gibco Co., Grand Island, N.Y., USA) with Earle's salts and L-glutamine was used (Krisher et al., 1999). For fertilization, Brackett-Oliphant (1975) medium was utilized and for culturing, modified synthetic oviductal fluid medium was used (Tervit et al., 1972).

\section{Oocyte collection and maturation}

Swamp buffalo ovaries $(n=610)$ were collected immediately postmortem at local abattoirs and transported to the laboratory in $0.9 \% \mathrm{NaCl}$ solution at $30-35^{\circ} \mathrm{C}$ within $4-6 \mathrm{~h}$. The ovaries were pooled irrespective of the donor's estrus cycle. Cumulus- oocyte complexes (COCs) were aspirated from antral follicles (3-5 $\mathrm{mm}$ in diameter) by using an 18 gauge needle attached to a $10 \mathrm{ml}$ sterile plastic syringe, washed three times in the maturation medium before selecting using a stereomicroscope (Ocampo et al., 1993). A group of 10-15 COCs were transferred into $50 \mu 1$ droplets of maturation medium under mineral oil (Sigma Chem Co., St. Louis, USA; Lot No. 29HO129) in a $35 \times 10 \mathrm{~mm}$ Falcon polysterene culture dish (Becton and Dickinson Labware, N.J., USA) which was previously pre-incubated to equilibrate for at least $2 \mathrm{~h}$ in a $\mathrm{CO}_{2}$ incubator. $\mathrm{COCs}$ were cultured at $39^{\circ} \mathrm{C}$ under an atmosphere of $5 \% \quad \mathrm{CO}_{2}$ and $95 \%$ air with high humidity. After culture for 22 hrs, the cumulus and corona cells were removed by pipetting.

\section{Sperm preparation}

Straws of locally processed Murrah buffalo (MB) frozen-semen from the Sperm Processing Unit of the Philippine Carabao Center at Central Luzon State University Ranch in Digdig, Carranglan, Nueva Ecija were thawed at $39^{\circ} \mathrm{C}$ water bath for $15 \mathrm{sec}$ and washed twice with fertilization medium containing $1 \mathrm{mg} / \mathrm{ml}$ BSA (Initial fractionation by heat shock, Sigma, St. Louis, MO, USA) by centrifugation at $800 \mathrm{~g}$ for $5 \mathrm{~min}$. After the final wash, the sperms were re-suspended (sperm concentration was based on the requirement of experimentation) in fertilization medium with caffeine $(6 \mathrm{mg} / \mathrm{ml})$ and BSA $(6 \mathrm{mg} / \mathrm{ml})$, and pre-incubated for 1 $\mathrm{h}$ at $39^{\circ} \mathrm{C}, 95 \%$ air atmosphere in a tightly capped test tube.

\section{In vitro fertilization and culture}

Selected oocytes were transferred to the fertilization droplets $(50 \mu \mathrm{l})$ with 15 oocytes per drop under mineral oil. A portion of sperm suspension was added to the droplets giving a final sperm concentration of $2 \times 10^{6} \mathrm{sperm} / \mathrm{ml}$ (applied in Expt. $1-3$ ), $3 \mathrm{mg} / \mathrm{ml}$ caffeine and $3 \mathrm{mg} / \mathrm{ml}$ BSA. The motility rate of sperm during insemination was more than $50 \%$. After spermoocyte co-culture for $24 \mathrm{hrs}$, the extra sperm cells attached to the oocytes were removed by pipetting using a finely drawn glass pipette. Subsequently, the oocytes were washed twice with culture medium before transferring to $50 \mu \mathrm{l}$ drops of mSOF medium and cultured for 7 days in a humidified incubator with a gas phase of $5 \% \mathrm{O}_{2}, 5 \% \mathrm{CO}_{2}$ and $90 \% \mathrm{~N}_{2}$ level at $39^{\circ} \mathrm{C}$.

\section{Analysis of the nuclear status}

Oocytes were fixed at $24 \mathrm{hrs}$ after maturation and $15 \mathrm{hrs}$ after insemination to examine the completion of $1^{\text {st }}$ meiosis and penetration of the oocytes, respectively. The eggs were mounted, fixed for $24 \mathrm{hrs}$ or more in $25 \%(\mathrm{v} / \mathrm{v})$ aceto/ethanol at room temperature, stained with $1 \%(\mathrm{w} / \mathrm{v})$ orcein in $45 \%(\mathrm{v} / \mathrm{v})$ acetic acid and examined under phase-contrast microscope at 200-400x 
magnification. The meiotic stage of the oocytes and the nuclear stage after penetration were assessed according to Ocampo et al. (1993). Oocytes with $2^{\text {nd }}$ metaphase plate and a polar body were regarded as matured (completed $1^{\text {st }}$ meiosis). Oocytes were designated as penetrated when they have at least one swollen sperm nucleus and/or a male pronucleus with corresponding sperm tail. Those with more than one penetrating/ swollen sperm head or male pronucleus were considered polyspermic.

\section{Cell counting}

Blastocyst appearing on the $7^{\text {th }}$ day were collected and subjected to a staining protocol with modification (Thouas et al., 2001). Briefly, blastocysts were washed in PBS-PVP, then placed in $1 \mathrm{ml}$ of Hoechts working solution $(0.75 \mathrm{ml}$ of $2.3 \% \mathrm{Na}$ citrate dehydrate solution; $0.25 \mathrm{ml}$ of ethanol; $10 \mu \mathrm{l}$ of Hoechts 33342 stock solution of $1 \mathrm{mg} / \mathrm{ml}$ concentration dissolved in ethanol) in an Effendorf tube, wrapped in aluminum foil and stored in the refrigerator for at least $24 \mathrm{~h}$. Subsequently, the blastocysts were recovered and washed in glycerol, mounted on a glass slide, flattened in glycerol by a cover slip to a level where all nuclei appeared at the same focal plane and examined by using a fluorescent microscope (Eclipse E-600; Nikon, Japan) under ultraviolet light. A digital image of each embryo was taken and the total cells (both inner cell mass and trophectoderm) were counted (Thouas et al., 2001).

\section{Experimental}

Experiment 1: Effect of oocyte quality on the nuclear maturation and fertilization. During oocyte collection, several COCs can be obtained with differing morphological characteristics. Since the success of in vitro fertilization is also dependent on oocyte quality, the selection of viable oocytes from the initial follicular fluid aspirate is necessary. COCs collected were classified based on the morphological characteristics of the cumulus cells surrounding the oocytes and the consistency of granulation for completion of $1^{\text {st }}$ meiosis and its subsequent fertilization. The oocytes were classified as follows: $\mathrm{O}_{1}$ - with compact multilayers of follicle cells and evenly granulated ooplasm, $\mathrm{O}_{2}-$ with compact multilayers of follicle cells and uneven granulation of the ooplasm, $\mathrm{O}_{3}$ - surrounded by 1-2 layers of cumulus cells with evenly granulated ooplasm, $\mathrm{O}_{4}-$ surrounded by 1-2 layers of cumulus cells with uneven granulation of the ooplasm and $\mathrm{O}_{5}-$ denuded oocytes.

Experiment 2: Effect of medium batch on the nuclear maturation and fertilization. COCs classified as $\mathrm{O}_{1}$ were cultured in TCM-199 medium (e.g., batch M4530 or M7528) and different concentrations of luteinizing hormone $(\mathrm{LH} ; 5 \mu \mathrm{g} / \mathrm{ml}$ or $10 \mu \mathrm{g} / \mathrm{ml})$ in addition to follicle stimulating hormone $(\mathrm{FSH} ; 0.5 \mu \mathrm{g} / \mathrm{ml}$ or 10 $\mu \mathrm{g} / \mathrm{ml})$ and estradiol $(1 \mu \mathrm{g} / \mathrm{ml})$ were added. After $24 \mathrm{~h}$ of culture, the oocytes were denuded free of cumulus cells by vortexing and the matured oocytes (distinguished by having a polar body) were collected and used for IVF.

Experiment 3: Bull-specific effect on the fertilization of IVM oocytes. In the establishment of a functional IVF protocol, it is necessary to have a common source of semen. It has been demonstrated that spermatozoa from individual bulls differ in their ability to fertilize in vitro (Chauhan et al., 1998). In this study, we tried to determine the difference of bull in their capablity to fertilize IVM oocytes for eventual embryo production.

Experiment 4: Effect of caffeine concentration on the fertilization of IVM oocytes. Caffeine and other cyclic nucleotide phosphodiesterase inhibitors have been used to stimulate mammalian sperm motility and metabolic activity. Also, it was reported that caffeine acts synergistically with heparin in inducing capacitation and acrosome reaction that results in improved penetration of IVM oocytes (Niwa and Ohgoda, 1988). In this study, we evaluated the penetrating capability of frozen-thawed spermatozoa after exposure to various concentrations of caffeine in an effort to partly establish the optimal caffeine concentrations needed for capacitation and acrosome reaction of buffalo spermatozoa.

Experiment 5: Effect of sperm concentration on the fertilization of IVM oocytes. In this study, sperm concentration of $1 \times 10^{6}, 5 \times 10^{6}$ and $10 \times 10^{6} \mathrm{sperm} / \mathrm{ml}$ were used to inseminate IVM oocytes.

Experiment 6: Effect of different culture conditions on developmental competence of zygotes derived from IVF of IVM oocytes. In this study, zygotes resulting from IVF of IVM oocytes were cultured in droplets of TCM199 medium or SOF medium with or without cumulus cell monolayer. Quality of resulting blastocyst was evaluated based on the total cell count.

\section{Statistical analysis}

Evaluation of differences between and among treatment groups of each experiment was done by using ANOVA for completely randomized design. The level of significance was set at $\mathrm{P}<0.05$.

\section{Results}

In Experiment 1, a total of 524 oocytes were evaluated on their capacity for completion of $1^{\text {st }}$ meiosis and fertilization post-insemination (p.i.) in vitro. These oocytes were randomly distributed according to the degree of presence or absence of cumulus cells and homogeneity of the cytoplasm (Table 1). The 
Res. Opin. Anim. Vet. Sci., 2016, 6(1): 24-31.

maturation rate was significantly higher $(\mathrm{P}<0.05)$ in oocytes with at least three layers of cumulus cells (70.4$78.7 \%$ ) compared to oocytes with lesser cumulus cells (57.9-61.8\%) or denuded oocytes $(60.0 \%)$. Also, the resulting fertilization rate was significantly high in $\mathrm{O}_{1}$ oocytes compared to $\mathrm{O}_{5}$ oocytes.

In Experiment 2, a total of 300 COCs were cultured in two batches of TCM-199 medium with different hormonal supplementation and evaluated for their capacity for completion of $1^{\text {st }}$ meiosis and fertilization p.i. in vitro. No significant differences were observed in the percentage of oocytes completing $1^{\text {st }}$ meiosis $(70.7-86.7 \%)$. Similarly, the fertilization rate in both conditions showed no significant differences ranging from 59.4 to $66.0 \%$ (Table 2).

In Experiment 3, 540 COCs were inseminated in vitro following IVM using semen from 4 Murrah bulls. Significant differences in the fertilization rate between bulls were observed and detailed in Table 3. In particular, the total number of oocytes fertilized when using semen from Murrah bulls (age $=5-7$ years) \# 39 (29.2\%) and \# 45 (34.2\%) were lower significantly than bulls \# 226 (58.0\%) and 228 (68.7\%).

In Experiment 4, a total of $210 \mathrm{COCs}$ were inseminated using semen from bull \# 228 which was exposed to different concentrations of caffeine. The fertilization rates obtained when using 3,5, $10 \mathrm{mg} / \mathrm{ml}$ caffeine. Whereas, the fertilization rate observed in the control was only $10.0 \%(\mathrm{P}<0.05)$. The monospermic fertilization rate in all treatments showed no significant differences (Table 4).

In Experiment 5, a total of $191 \mathrm{COCs}$ were inseminated using semen from bull \# 228 at different sperm concentration. The fertilization rates obtained when using $1 \times 10^{6}$ sperm $/ \mathrm{ml}$ concentration was $43.0 \%$ with monospermic percentage of $64.5 \%$. Whereas, the fertilization rates observed when using 5-10 $\times 10^{6}$ sperm $/ \mathrm{ml}$ concentration ranged from $68.4-71.0 \%$ with monospermic percentage of 36.0 - $56.8 \%$ (Table 5 ).

In Experiment 6, a total of 212 cleaved embryos resulting from IVF were cultured in TCM-199 or SOF medium with or without cumulus cell monolayer. The blastocyst formation rate observed on the $7^{\text {th }}$ day ranged from $11.5-22.2 \%$ in all treatments. Similarly, the total cell count showed no significant difference.

\section{Discussion}

The opportunity of collecting oocytes from the ovaries of slaughtered swamp buffalo was limited considering the fact that some antral follicles are inside the ovary. The number of visible follicles on the surface of the ovaries ranged from $0-10$ follicles, confirming the previous observations done in both swamp and riverine buffaloes (Jainudeen et al., 1993). The mean number of COCs obtained per ovary was 3 .
Table 1: Effect of oocyte quality on the completion of $1^{\text {st }}$ meiosis and its subsequent fertilization

\begin{tabular}{clccc}
\hline Type of & \multicolumn{4}{c}{ No. of oocytes (\%) } \\
\cline { 2 - 5 } oocytes & Cultured & Matured & Inseminated & Fertilized \\
\hline $\mathrm{O}_{1}$ & 150 & $118(78.7)^{\mathrm{a}}$ & 115 & $73(63.5)^{\mathrm{a}}$ \\
$\mathrm{O}_{2}$ & 108 & $76(70.4)^{\mathrm{a}, \mathrm{b}}$ & 76 & $45(59.2)^{\mathrm{a}, \mathrm{b}}$ \\
$\mathrm{O}_{3}$ & 110 & $68(61.8)^{\mathrm{b}}$ & 65 & $36(55.4)^{\mathrm{a}, \mathrm{b}}$ \\
$\mathrm{O}_{4}$ & 76 & $44(57.9)^{\mathrm{b}}$ & 44 & $23(52.3)^{\mathrm{a}, \mathrm{b}}$ \\
$\mathrm{O}_{5}$ & 60 & $36(60.0)^{\mathrm{b}}$ & 36 & $17(47.2)^{\mathrm{b}}$ \\
\hline
\end{tabular}

${ }_{\mathrm{a}, \mathrm{b}}$ Values with different superscript in the same column differ significantly $(\mathrm{P}<0.05)$. Data was taken from 5 replicates

Table 2: Effect of medium batch on the completion of $1^{\text {st }}$ meiosis and its subsequent fertilization

\begin{tabular}{llllll}
\hline \multirow{3}{*}{ Media } & \multicolumn{5}{c}{ No. of oocytes (\%) } \\
\cline { 2 - 6 } & \multicolumn{4}{c}{ Treatment } \\
\cline { 2 - 6 } & Cultured & Matured & Inseminated Fertilized \\
\hline Batch (4530) & A & 75 & $54(72.0)$ & 50 & $33(66.0)$ \\
& B & 75 & $65(86.7)$ & 64 & $38(59.4)$ \\
Batch (7528) & A & 75 & $53(70.7)$ & 53 & $34(64.2)$ \\
& B & 75 & $60(80.0)$ & 60 & $37(61.7)$ \\
\hline
\end{tabular}

Data taken from 5 replicates. A - LH $(5 \mu \mathrm{g} / \mathrm{ml})$, FSH $(0.5$ $\mu \mathrm{g} / \mathrm{ml})$, estradiol $(1 \mu \mathrm{g} / \mathrm{ml})$; B - LH $(10 \mu \mathrm{g} / \mathrm{ml})$, FSH $(10$ $\mathrm{ug} / \mathrm{ml})$, estradiol $(1 \mu \mathrm{g} / \mathrm{ml})$.

Table 3: Bull-specific effect on the penetration of IVM oocytes

\begin{tabular}{lcc}
\hline Bull & \multicolumn{2}{c}{ No. of oocytes $(\%)$} \\
\hline No. & Inseminated & Penetrated \\
\hline 39 & 120 & $35(29.2)^{\mathrm{a}}$ \\
45 & 120 & $41(34.2)^{\mathrm{a}}$ \\
226 & 150 & $87(58.0)^{\mathrm{b}}$ \\
228 & 150 & $103(68.7)^{\mathrm{b}}$ \\
\hline
\end{tabular}

a,b Values with different superscript in the same column differ significantly $(<0.05)$. Data taken from 10 replicates.

The criteria used for the selection of oocytes based on the degree of presence of cumulus cells and granulation of ooplasm using light microscopic assessment could be useful for future IVM/IVF/IVC studies. The results have shown that oocytes with or without cumulus cells and/or with even or uneven granulation of the ooplasm could undergo meiotic resumption and subsequent completion of $1^{\text {st }}$ meiosis better than denuded oocytes. These findings concur with the observations in other mammalian species (Fukui et al., 1980; De Smedt et al., 1992; Ocampo et al., 1993). Apparently, the intercellular cooperation between the oocytes and cumulus cells via gap junctions is necessary for the growth of oocytes to proceed, most likely by taking up nutrients from the culture medium. Also, the results further substantiate the fact that oocytes surrounded with multilayers of cumulus cells at the time of maturation is a necessary pre-requisite for the acquisition of oocytes developmental competence as reflected by a significantly higher fertilization rate of $\mathrm{O}_{1}$ oocytes than $\mathrm{O}_{5}$ oocytes. It is well known that the growth of the oocyte, the acquisition of developmental competence 
Table 4: Effect of caffeine on the penetration of IVM oocytes

\begin{tabular}{ccccc}
\hline \multicolumn{2}{c}{ Caffeine } & \multicolumn{4}{c}{ No. of oocytes (\%) } \\
\hline \multicolumn{4}{c}{ conc $(\mathrm{mg})$ Inseminated Penetrated } & Monospermic Polyspermic \\
\hline 0 & 50 & $5(10.0)^{\mathrm{a}}$ & $3(60.0)$ & $2(40.0)$ \\
3 & 52 & $24(46.2)^{\mathrm{b}}$ & $14(58.3)$ & $10(41.7)$ \\
5 & 52 & $27(51.9)^{\mathrm{b}}$ & $16(59.3)$ & $11(40.7)$ \\
10 & 56 & $29(51.8)^{\mathrm{b}}$ & $17(58.6)$ & $12(41.4)$ \\
\hline
\end{tabular}

${ }^{\text {a.b }}$ Values with different superscript in the same column differ significantly $(\mathrm{P}<0.05)$. Data taken from 5 replicates. Semen sample was from MB \# 228.

Table 5: Effect of sperm concentration on the penetration of IVM oocytes

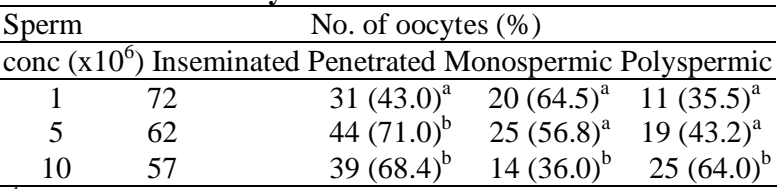

${ }^{\mathrm{a}, \mathrm{b}}$ Values with different superscript in the same column differ significantly. Data taken from 6 replicates. Semen sample was from MB \# 228.

Table 6: Effect of culture systems on the development of zygotes to the blastocyst stage

\begin{tabular}{lcccc}
\hline \multicolumn{2}{l}{ Culture } & \multicolumn{3}{c}{ No. of embryos (\%) } \\
\hline \multicolumn{2}{l}{ Conditions } & Cultured & Blastocyst & Total cell count \\
\hline \multicolumn{2}{l}{ TCM-199 (-) } & 52 & $6(11.5)$ & $84.6 \pm 11.2$ \\
& $(+)$ & 55 & $11(20.0)$ & $86.6 \pm 9.1$ \\
SOF & $(-)$ & 51 & $10(19.6)$ & $91.4 \pm 12.2$ \\
& $(+)$ & 54 & $12(22.2)$ & $87.4 \pm 14.0$ \\
\hline
\end{tabular}

Data taken from 5 replicates.

and complete meiotic and cytoplasmic maturation of the oocyte, is critically dependent on the oocyte's association with follicular somatic cells including the cumulus cells (Gilchrist et al., 2007).

Although completion of $1^{\text {st }}$ meiosis in buffalo oocyte can be achieved in the absence of hormones (Madan et al., 1994a,b), its maturation and fertilization rates were nonetheless reported to be higher with hormone supplementation (Totey et al., 1992). The beneficial effect of hormone supplementation is dependent on the choice of medium for IVM. For instance, in Ham's F-10 medium, LH alone improved the maturation while FSH and estradiol failed to synergize with LH. In TCM-199 medium, LH alone failed to improve the maturation rate, whereas addition of FSH and estradiol did improve the maturation rate (Younis et al., 1989; Totey et al., 1993b). In this study, the use of two batches of TCM-199 supplemented with different concentrations of hormones showed no significant difference in supporting the maturation of SB oocytes and its subsequent fertilization in vitro ranging from $70.7-86.7 \%$ and $59.4-66.0 \%$, respectively.

A high degree of variability in bovine and ovine IVF have been observed after using semen from different source, indicating differences in sperm capacitation, acrosome reaction and fertilization (Iritani et al., 1986; Fukui et al., 1988a,b). In buffalo, similar variations on the fertilizing capability and subsequent embryonic development in vitro among individual bulls have been reported (Chauhan et al., 1998). In this study, the fertilizing capability of 2 selected bulls (\# 226 and \# 228) were observed higher significantly than the other 2 bulls (\# 39 and \# 45). These findings provided further evidence that bull variability significantly influence the outcome of fertilization rate in vitro. The protocol adopted in handling and processing of semen samples have been standardized to minimize discrepancies that may influence the expected result. Similarly, the sperm motility prior to insemination and the final sperm concentration in the droplets of fertilization medium have been strictly monitored before introducing the oocytes. Despite these considerations, variable results were obtained enabling us to identify which bulls would provide a better fertilization rate.

The initial results on the IVF of SB oocytes was limited by low cleavage rate, despite having a fertilization rate of more than $50.0 \%$. Thus, optimization of the protocol being used is deemed necessary. In Experiment 4, the effect of caffeine, in a dose dependent manner, was used to induce the capacitation of semen from bull \# 228 for fertilization of IVM SB oocytes. Complete capacitation of sperm is a critical step in IVF protocol and caffeine was reported to be effective in enhancing sperm motility and improving fertilization rate in buffalo (Bacci et al., 1991; Madan et al., 1994a,b; Chauhan et al., 1997), although some variations were observed particularly in the cleavage rate. In this study, the addition of 3-10 $\mathrm{mg} / \mathrm{ml}$ caffeine during sperm-oocyte coincubation showed no difference on the penetration rate but was significantly higher than the control, indicating the beneficial effect of including caffeine in the fertilization droplets. Others have used heparin alone (Boni et al., 1994a,b;1999; Gasparrini et al., 2000; Neglia et al., 2001) or in combination with caffeine (Totey et al., 1992), theophylline (Jainudeen et al., 1993; Aquino et al., 2015) or a mixture of penicillamine, hypotaurine and epinephrine (Totey et al., 1996). High variability in the fertilizing ability of different bulls have also been reported dependent on the agent used for capacitation (Chauhan et al., 1998). Thus, screening the spermatozoa of individual bulls for IVF studies had become a necessity.

The use of $2 \times 10^{6}$ sperm $/ \mathrm{ml}$ concentration during sperm-oocyte co-incubation was reported to yield a high fertilization rate without increasing polyspermy (Boni et al., 1999): Similarly, in the first 3 experiments of this study, $2 \times 10^{6} \mathrm{sperm} / \mathrm{ml}$ concentration was used with more than $50.0 \%$ fertilization rate. Reducing this to $1 \times 10^{6} \mathrm{sperm} / \mathrm{ml}$ concentration resulted to reduced 
fertilization rate as compared to $5,10 \times 10^{6} \mathrm{sperm} / \mathrm{ml}$ concentration but with higher monospermic fertilization rate. Increased sperm concentration resulted in a decreased monospermic fertilization rate $(36.0 \%)$. In another study, buffalo oocytes inseminated with $5,10 \times$ $10^{6} \mathrm{sperm} / \mathrm{ml}$ concentration had a cleavage rate of 40 $56 \%$ (Nandi et al., 1998), but did not specify if all cleaved embryos were of monospermic fertilization or with parthenotes. Nonetheless, the occurrence of normal fertilization rate is also influenced by the length of sperm-oocyte co-incubation. In this study, coincubation of sperm-oocyte during fertilization was for $24 \mathrm{~h}$. It was reported that incubation of $24 \mathrm{hrs}$ with $2 \times$ $10^{6} \mathrm{sperm} / \mathrm{ml}$ gave better fertilization rates than with 1 , $3,4 \times 10^{6}$ sperm $/ \mathrm{ml}$ concentration. Using high concentration of sperm during fertilization, spermoocyte co-incubation could be reduced to $6 \mathrm{~h}$ with still improved fertilization rates without affecting the postfertilization embryonic development (Totey et al., 1993a). In this experiment, the use of bull \# 228's spermatozoa at $1,5 \times 10^{6} \mathrm{sperm} / \mathrm{ml}$ concentration during sperm-oocyte co-incubation for $24 \mathrm{~h}$ seems ideal for fertilization SB oocytes in vitro.

In vitro efficient buffalo embryo production depends on the identification of a suitable culture system that would support embryonic development up to the blastocyst stage. Earlier studies have used buffalo oviductal epithelial cell co-culture system to support embryonic development up to the blastocyst stage (Chuangsoongneon and Kamonpatana, 1991; Jainudeen et al., 1993; Totey et al., 1992), but with poor efficiency $(8.2 \%)$. The inclusion of cumulus cell monolayer with oviductal epithelial cells improved the blastocyst formation rate of cleaved embryos (Madan et al., 1994a). Others have successfully used buffalo rat liver cell monolayer (Boni, 1995; 1999), Vero cells (Gasparrini, 2002) or chick embryo amniotic fluid (Ocampo et al., 1994), which were attributed to the secretion of embryotrophic factors like growth factors-I (e.g., IGF-I) (Narula et al., 1996). In this study, the use of either TCM-199 and SOF media in supporting the development of cleaved embryos to the blastocyst stage showed no difference, although blastocyst formation rate was higher with cumulus cell monolayer. It was proposed that somatic cells secrete embryotrophic factors, remove potentially harmful compounds and modify medium components to level more appropriate for embryo development and lower $\mathrm{O}_{2}$ tension in proximity of the embryos, thus reducing oxidative damages caused by reactive oxygen species (Bavister, 1995). However, the inclusion of serum and/or somatic cells in the IVC medium makes the understanding of the metabolic and biochemical requirements for buffalo embryo development in vitro more complicated and difficult. Thus, the use of a chemically defined system for culture has been suggested. When SOF medium was used with a lowered oxygen tension (7\%) in the culture environment, higher blastocyst rate was obtained than with the co-culture system. Also, development of the embryos to the blastocyst stage was observed one day earlier than embryos co-cultured with somatic cells (Boni et al., 1999). In this study, the blastocyst formation rate and total cell count of embryos derived from mSOF culture was higher than TCM-199 with/without cumulus cells though not significant. In another study, MB and SB oocytes obtained through ovum pick-up and from the abattoir, respectively were subjected to IVM/IVF/IVC system using mSOF as a single based medium resulted in a higher blastocyst formation rate than when using sequential culture system (Ocampo et al., 2013). These findings showed the usefulness and practicality of considering $\mathrm{mSOF}$ base medium for supporting buffalo oocytes acquisition of developmental competence in an in vitro culture system.

\section{Conclusion}

Selection of appropriate bull, its optimum sperm concentration, the choice of capacitating agent and its concentration, the type of medium for culture of resulting zygotes is critical for successful application of in vitro maturation, fertilization and culturing for mass production of buffalo embryos.

\section{References}

Aquino LM, Manaois FV, Ocampo LC, Ocampo MB (2015) Evaluation of bioassay using in vitro matured water buffalo oocytes in predicting bull sperm fertility. J Agric Tech, 11: 2531-2538.

Bacci ML, Galeati G, Mattioli M, Boni R, Seren E (1991) In vitro maturation and fertilization of buffalo oocytes. Proc 3rd World Buffalo Cong., 599-603.

Bavister BD (1995) Culture of pre-implantation embryos: Facts and artifacts. Hum Reprod Update: 1: 91-148.

Boni R (1994a) In vitro production in bovine and buffalo species. Buffalo J, Suppl, 2: 147-160.

Boni R, Roviello S, Barbieri V, Zicarelli L (1994b). In vitro embryo production in buffalo species. Atti XLVIII Convegno Nazionale SISVET, 1994b: 1: 307-312.

Boni R, Roviello S, Gasparrini B, Langella M, Zicarelli $\mathrm{L}$ (1999) In vitro production of buffalo embryos in chemically defined medium. Buffalo J, 1: 115-120.

Brackett BG, Oliphant G (1975) Capacitation of rabbit spermatozoa in vitro. Biol Reprod, 12: 260-274.

Chauhan MS, Katiyar PK, Singla SK, Manik RS, Madan ML (1997) Production of buffalo calves through IVF. Indian J Anim Sci, 67: 306-308. 
Chauhan MS, Singla SK, Palta P, Manik RS, Madan ML (1998) Individual variation among buffalo bulls in fertilization and subsequent embryonic development in vitro. Indian J Anim Sci, 68: 454456.

Chuangsoongneon U, Kamonpatana M (1991) Oocyte maturation, in vitro fertilization and culture system for developing pre-implantation swamp buffalo embryos using frozen-thawed semen. Buffalo $\mathrm{J} 7$ : 189-198.

Dauzier L, Thibault C, Wintenberger S (1954) La fecundation in vitro de l'oeuf de la lapine. CR Acad Sci, Paris 238:844-845.

De Smedt V, Crozet N, Ahmed-Ali M, Martino A, Cognie $\mathrm{Y}$ (1992). In vitro maturation and fertilization of goat oocytes. Theriogenology, 37: 1049-1060.

Fukui Y, Sakuma Y (1980) Maturation of bovine oocytes cultured in vitro; relation to ovarian activity, follicular size and the presence or absence of cumulus cells. Biol Reprod, 22: 669-673.

Fukui Y, Glew AM, Gandolfi F, Moor RM (1988a) IVC of sheep oocytes matured and fertilized in vitro. Theriogenology, 29: 883-891.

Fukui Y, Glew AM, Gandolfi F, Moor RM (1988b). Ram-specific effects on in vitro fertilization and cleavage of sheep oocytes matured in vitro. Journal of Reprod Fertil, 82: 337-340.

Gasparrini B, Neglia G, Di Palo R, Campanile G, Zicarelli L (2000). Effect of cysteamine during in vitro maturation on buffalo embryo development. Theriogenology, 54: 1537-1542.

Gasparrini B (2002). In vitro embryo production in buffalo species: state of the art. Theriogenology, 57: 237-256.

Gilchrist RB, Thompson JG (2007). Oocyte maturation: Emerging concepts and technologies to improve developmental potential in vitro. Theriogenology, 67: 6-15.

Hufana-Duran D, Aquino FP, De Vera RV, Pedro PB, Cruz LC (1998). Some physical factors affecting development of buffalo oocytes matured and fertilized in vitro. Korean J Anim Reprod., 21: 265-272.

Hufana-Duran D, Pedro PB, Venturina HV, Hufana RD, Salazar AL, Duran PG, Cruz LC (2004). Postwarming hatching and birth of live calves following transfer of in vitro derived vitrified water buffalo embryos. Theriogenology, 61: 1429-1439.

Hufana-Duran D, Pedro PB, Venturina HV, Duran PG, Cruz LC (2005) Full term development of in vitro produced vitrified water buffalo embryos. Phil J Sci, 134: 89-94.

Hufana-Duran D, Pedro PB, Salazar AL, Venturina HV, Duran PG, Cruz LC (2008). Twin calf production in water buffaloes following non- surgical transfer of in vitro produced-vitrified embryos. Phil J Sci, 137: 99-104.

Iritani A, Utsumi K, Miyake M, Yanagimachi Y (1986). Individual variation in the IVF ability of bull spermatozoa. Dev Growth Differ, Suppl, 28:45.

Jainudeen MR, Takahashi Y, Nihayah M, Kanagawa H (1993). In vitro maturation and fertilization of swamp buffalo oocytes. Anim Reprod Sci, 31: $205-$ 212.

Krisher RL, Lane M, Bavister BD (1999). Developmental competence and metabolism of bovine embryos cultured in semi-defined and defined culture media. Biol Reprod., 60: 13451352.

Madan ML, Chauhan MS, Singla SK, Manik RS (1994a) Pregnancies established from water Buffalo blastocyst derived from IVM/IVF oocytes and co-cultured with cumulus and oviductal cells. Theriogenology, 42: 591-600.

Madan ML, Singla SK, Chauhan MS, Manik RS (1994b). In vitro production and transfer of embryos in buffaloes. Theriogenology, 41: 139143.

Nandi S, Chauhan MS, Palta P (1998). Effect of cumulus cells and sperm concentration on cleavage rate and subsequent embryonic development of buffalo oocytes matured and fertilized in vitro. Theriogenology, 50: 1251-1262.

Narula A, Taneja M, Totey SM (1996). Morphological development, cell number and allocation of cells to trophectoderm and inner cell mass of in vitro fertilized and parthenogenetically developed buffalo embryos; effect of IGF-I. Mol Reprod Dev, 44: 343-351.

Neglia, G, Gasparrini B, Caracciolo Di Brienza V, Campanile G, Spadetta M, Zicarelli L (2001) Cryopreservation of in vitro produced buffalo and bovine embryos by vitrification. VI World Buffalo Cong., Venezuela, Maracaibo. 6:155-159.

Niwa K, Ohgoda O (1988) Synergistic effect of caffeine and heparin on IVF of cattle oocytes matured in culture. Theriogenology, 30: 733-741.

Ocampo MB, Ocampo LC, Ryu IS, Ueda J, Mori T, Kanagawa H (1993). Effect of culture time, ovarian activity, cumulus cells and sera on the nuclear and cytoplasmic maturation of pig oocytes in vitro. Anim Reprod Sci, 34: 135-146.

Ocampo LC, Ocampo MB, Aquino FP, De Vera RV, Cruz LC (1996a) Blastocyst formation of swamp buffalo embryos in co-culture systems. Proc $2^{\text {nd }}$ ABA Cong, Manila, Philippines, 2: 412-416.

Ocampo MB, Ocampo LC, Lorenzo ND, Mamuad FV, Aquino FP, Mori T, Shimizu H, Cruz LC (2000). Live births resulting from swamp buffalo oocytes matured, fertilized and cultured in vitro. Austr J Anim Sci, 13: 279-281. 
Ocampo LC, Ocampo MB, Mamuad FV, Venturina EV, Mori T, Shimizu H (2001a). Timing of sequential changes on chromosome configurations during the $1^{\text {st }}$ meiosis, $2^{\text {nd }}$ meiosis and cytoplasmic events of swamp buffalo oocytes matured and fertilized in vitro. Phil J Vet Anim Sci, 27: 1-11.

Ocampo LC, Mamuad FV, Mori T, Shimizu H, Ocampo MB (2001b). In vitro production of pre-implantation buffalo embryos. Buffalo J, 19: 145-154.

Ocampo LC, Ocampo MB, Mamuad FV, Venturina EV, Mori T, Shimizu H (2002). Intracytoplasmic GSH concentration of swamp buffalo oocytes cultured in vitro. Bull., 19: 27-29.

Ocampo LC, Duran DH, Pedro PB, Aquino FP, Atabay EP, Ocampo MB, Maylem ES, Duran PG, Cruz LC (2013). Developmental competence of buffalo oocytes in vitro in single base medium SOF. Buffalo Bull, 32: 551.

Tervit HR, Whittingham DG, Rowson LE (1972). Successful culture in vitro of sheep and cattle ova. J Reprod Fertil, 30: 493-497.

Thouas GA, Korfiatis NA, French AJ, Jones GM, Trounson AO (2001) Simplified technique for Differential staining of inner cell mass and trophectoderm cells of mouse and bovine blastocysts. Reprod Biomed, 3: 25-29.

Totey SM, Singh G, Taneja M, Pawshe CH, Talwar GP (1992). In vitro maturation, fertilization and development of follicular oocytes from buffalo. J Reprod Fertil, 95: 597-607.

Totey SM, Pawshe CH, Singh GP (1993a) Effects of bull and heparin, sperm concentration on IVF of buffalo oocytes matured in vitro. Theriogenology, 39: 887-898.

Totey SM, Pawshe CH, Singh GP (1993b). In vitro maturation and fertilization of buffalo oocytes; Effects of media, hormones and sera. Theriogenology, 39: 1153-1171.

Totey SM, Daliri M, Appa Rao KBC, Pawshe CH, Taneja M, Chillar RS (1996). Differential cleavage and developmental rates and their correlation with cell number and sex ratios in buffalo embryos generated in vitro. Theriogenology, 45: 521-533.

Younis AL, Brackett BG, Fayner-Hosken RA (1989) Influence of serum and hormones on bovine oocyte maturation and IVF. Gamete Res, 23:189-201.

Ocampo MB, Ocampo LC (2015). A protocol for the in vitro production of bubaline embryos: The Philippine experience. J Agric Tech., 11: 23432357.

Ocampo MB, Ocampo LC, Mori T, Ueda J, Kanagawa $\mathrm{H}$ (1994) Blastocyst formation of pig embryos derived from in vitro fertilization of pig oocytes matured in vitro in the amniotic fluid of a developing chick embryos. Anim Reprod Sci, 37: 65-73. 